\title{
EFFECT OF ARBUSCULAR MYCORRHIZAL FUNGI AND SOIL PHOSPHORUS LEVEL ON EXPRESSION OF PROTEIN AND ACTIVITY OF PEROXIDASE ON PASSION FRUIT ROOTS
}

\author{
SANTOS, B. A., ${ }^{1}$ MAIA, L. C., ${ }^{1}$ CAVALCANTE, U. M. T., ${ }^{3}$ CORREIA, M. T. S. ${ }^{2}$ and \\ COELHO, L. C. B. B. ${ }^{2}$ \\ ${ }^{1}$ Laboratório de Micorrizas, Departamento de Micologia, Universidade Federal de Pernambuco, \\ Cidade Universitária, CEP 50670-420, Recife, PE, Brazil \\ ${ }^{2}$ Laboratório de Glicoproteínas, Departamento de Bioquímica, Universidade Federal de Pernambuco, \\ Cidade Universitária, CEP 50670-420, Recife, PE, Brazil \\ ${ }^{3}$ Departamento de Biologia, Universidade Federal Rural de Pernambuco, Dois Irmãos, Recife, PE, Brazil \\ Correspondence to: Leonor Costa Maia, Departamento de Micologia, CCB, UFPE, Rua Prof. Nelson Chaves, s/n, \\ CEP 50670-420, Recife, PE, Brazil, e-mail: leonorcmaia@hotmail.com \\ Received July 19, 2000 - Accepted November 7, 2000 - Distributed November 30, 2001
}

(With 1 figure)

\begin{abstract}
The effects of mycorrhizal inoculation and increasing soil $\mathrm{P}$ levels on the expression of total proteins and peroxidase activity on passion fruit roots were evaluated. The experimental design was entirely at random, with four treatments of inoculation ( $\mathrm{a}$ - control; $\mathrm{b}$ - Gigaspora albida; c - Scutellospora heterogama; d - mixture of G. albida, G. margarita, S. heterogama, and Glomus clarum) $\times$ three levels of soil P $\left(4,11\right.$, and $30 \mathrm{mg} / \mathrm{dm}^{3}$ of soil), each with three replicates. Plants were harvested 70 days after inoculation, when root colonization, shoot $\mathrm{P}$ level, protein content, and enzymatic activity of peroxidase (PAGE - 7\%) on root extract were evaluated. Regarding protein, there was no significant difference among the treatments, except between those roots receiving mixed inoculum and $11 \mathrm{mg} \mathrm{P} / \mathrm{dm}^{3}$ of soil. Effect of $\mathrm{P}$ on protein concentration, when compared with the inoculation effect was observed. For peroxidase, there was an eletrophoretic band common to all treatments (rf: 0.43) and another that was absent only in noncolonized plants, grown in soil with lower P (rf: 0.46). Mycorrhizal specific bands were not present but a small decrease of intensity of bands in noncolonized plants was observed. Conversely, the control roots presented a single band (rf: 0.33 ) not observed in the other extracts, that may demonstrate an inhibitory effect of AMF on some host activities. The data showed the influence of $\mathrm{P}$ level in soil on the protein expression of roots, suggesting the influence of this nutrient on root genetic expression as well as on the mechanisms of symbiotic control/recognition.
\end{abstract}

Key words: mycorrhiza, root proteins, peroxidase, passion fruit.

\section{RESUMO}

Efeito dos fungos micorrízicos arbusculares e dos níveis de fósforo no solo sobre a expressão de proteínas e a atividade da peroxidase em raiz de maracujazeiro-amarelo

$\mathrm{O}$ efeito da inoculação micorrízica e de crescentes níveis de $\mathrm{P}$ no solo sobre a expressão de proteínas e a atividade da peroxidase foi avaliado em raízes de maracujazeiro-amarelo (Passiflora edulis f. flavicarpa Deg.). O arranjo experimental foi feito totalmente ao acaso com quatro tratamentos de inoculação com fungos micorrízicos arbusculares, FMA (a - controle, b - Gigaspora albida, c - Scutellospora heterogama e d - mistura de G. albida, S. heterogama, G. margarita e Glomus clarum) $\times$ três níveis de $\mathrm{P}$ no solo $\left(4,11\right.$ e $30 \mathrm{mg} / \mathrm{dm}^{3}$ de solo) com três repetições. As plantas foram colhidas aos 70 dias de inoculação, para avaliação da colonização micorrízica, determinação do $P$ na parte 
aérea, estimativa do conteúdo protéico e avaliação da atividade enzimática da peroxidase (em gel de poliacrilamida - PAGE - 7\%) nos extratos radiculares. Nos valores de proteína, não houve diferença significativa, exceto entre as raízes tratadas com inóculo misto e $11 \mathrm{mg} \mathrm{de} \mathrm{P} / \mathrm{dm}^{3}$ de solo e as plantas crescidas com G. albida em solo com $30 \mathrm{mg}$ de P/ $/ \mathrm{dm}^{3}$ de solo. Observou-se influência destacada do $\mathrm{P}$ sobre a concentração protéica, quando comparado com o efeito fúngico. Para peroxidase, evidenciouse a formação de uma banda eletroforética comum a todos os tratamentos (rf: 0,43 ) e outra que foi ausente apenas nas plantas não colonizadas, crescidas em solo com menores concentrações de P (rf: 0,46). Não foram notadas bandas micorrízicas específicas nos extratos, mas uma pequena diminuição na intensidade em bandas de plantas não colonizadas. Porém, a raiz controle apresentou uma banda única (rf: 0,33), não presente nos demais extratos, o que demonstra, talvez, um efeito inibitório dos FMA sobre algumas atividades do hospedeiro. Os dados demonstram a influência do nível de P no solo sobre a expressão protéica radicular, sugerindo a influência desse elemento na expressão gênica radicular, bem como nos mecanismos de controle/reconhecimento simbiótico.

Palavras-chave: micorriza, proteínas radiculares, peroxidase, maracujá.

\section{INTRODUCTION}

Arbuscular mycorrhiza are mutualistic associations with great ecological and economical importance, formed between some fungi (Glomales) and roots of most plant species, in natural and agricultural ecosystems. Much has been speculated regarding the molecular bases that direct the functional integrity of endomycorrhiza; however, little is known about these mechanisms (GianinazziPearson \& Gianinazzi, 1995). Physiological and biochemical alterations have been observed in mycorrhizal roots, with production of specific proteins (endomycorrhizins) which are probably related with aspects of recognition between the symbionts (Gianinazzi-Pearson, 1992; Lambais, 1996). The differential expression of some proteins, as well as the mycorrhizal colonization may be regulated by the plant P level (Gianinazzi et al., 1992).

There are few observations related with specific products of colonization by endomycorrhizal fungi, including the arbuscular (Gianinazzi et al., 1992). Gianinazzi-Pearson \& Gianinazzi (1995) compared a few studies and observed that there are more results showing higher protein concentration in mycorrhizal plants, the majority of them with unknown functions. However, other analyses do not show this effect, which indicates that further studies should be performed for better comprehension of this phenomenon.

Hepper \& Sem (1986) investigated the enzymatic and proteic components of spores of AMF and mycorrhizal roots, observing similar activities for peptidases and malato dehydrogenase and others for sterases in different fungal species. These authors mentioned that the proteic pattern in the treatments was relatively constant for spores and hypha (external and internal) during mutualism, while roots (mycorrhizal or not) varied in the band pattern. Additional information regarding variability of the proteic pattern in isolated species and physiological stages of AMF spores was presented by Avio \& Giovannetti (1998): Glomus mosseae and G. caledonium presented equal patterns of bands, independently of the associated host, while different isolates of $G$. coronatum showed the same protein pattern. It was further mentioned that the physiological state of spores may also change the quantity and quality of bands.

Mohr et al. (1998) analysed in detail defense gene expression in bean roots (Phaseolus vulgaris L.) colonized by an AMF (G. mosseae) and a phytopathogenic fungus (Fusarium solani f. sp. phaseoli).

They observed that mycorrhizal colonization had no effect on the expression of plant defense genes, as opposed to the expressive increase of enzymatic activity found in the pathogenic interaction compatible with the Fusarium, which was related with production of chitinase, glucanase, and PAL (phenilalanine ammoniumliase). These data differ from results of other investigations, where in general production and activation of enzymes during plant mycothophy have shown similarities between fungal infection processes and the early stages of development of endomycorrhizas (Bonfante-Fasolo \& Spanu, 1994). 
The activity of peroxidase in arbuscular mycorrhiza has been mapped because this enzyme functions as a barrier to fungi invasion of plant tissues, as a characteristic marker of stress situations. Spanu \& Bonfante-Fasolo (1988) evaluated peroxidase activity in cell walls in garlic plants colonized by Glomus versiforme. They observed that the higher points of activity occur at the beginning of symbiotic establishment, although in more advanced stages the activity had decreased to the same level of non-mycorrhizal plants. These data are quite different from those presented by Dehne \& Schönbeck (1978) who showed increase of peroxidase activity in mycorrhizal plants, even working with enzymes from extracts, in a fixed observation time.

The data available indicate the need for investigations about protein and enzymes synthesized in mycorrhizal plants, which are valuable tools for the ecophysiological understanding of the association, and possible factors of regulation, of the mutualistic partners. In this study we evaluated the variation on protein expression and peroxidase activity in roots of passion fruit colonized by AMF species and maintained in soils with increasing phosphorus levels.

\section{MATERIAL AND METHODS}

The experiment was performed in a greenhouse in natural conditions of temperature, light, and humidity. The maximum and minimum averages for temperature and humidity were respectively: $38.6^{\circ} \mathrm{C}$ and $19.6^{\circ} \mathrm{C}, 90 \%$ and $33 \%$.

\section{Fungal isolates}

Four isolates of AMF from pot cultures with Paspalum notatum Flugge were used: Gigaspora albida Schenck \& Smith (INVAM, 927), Gigaspora margarita Becker \& Hall, Glomus clarum Nicolson \& Schenck, and Scutellospora heterogama (Nicolson \& Gerdemann) Walker \& Sanders (Embrapa/CNP Agrobiologia, UFPE 02, 08, and 12 , respectively).

\section{Substrate and P levels}

A red yellow Podzol was used for the experiments; its characteristics are shown in Table 1. The soil was sterilized with methyl bromite, 20 days before used. Three levels of $\mathrm{P}$ in the soil solution were tested $\left(4,11\right.$, and $30 \mathrm{mg} / \mathrm{dm}^{3}$ of soil) based on nutrient recommendations for this crop (Cavalcanti et al., 1998) and using superphosphate $\left(\mathrm{P}_{2} \mathrm{O}_{5}\right)$. Soil moisture was maintained at $60 \%$ of total pore volume (TPV).

\section{Plant material and mycorrhizal inoculation}

Seeds of passion fruit were allowed to germinate in sterilized soil, after desinfection with $20 \%$ sodium hypochlorite $/ 2 \mathrm{~min}$. and being rinsed with distilled sterilized water.

Eight days after germination, seedlings of $4.5 \mathrm{~cm}$ height with only one true leaf were transferred to plastic containers with $40 \mathrm{~g}$ of soil, and inoculated with AMF. All inoculated treatments received 100 spores from either one species $(G$. albida or $S$. heterogama) or from four species ( $G$. albida, G. margarita, S. heterogama, and $G$. clarum), in this case, 25 spores from each species.

TABLE 1

Characterization of the red yellow Podzol soil used for the experiments.

\begin{tabular}{|c|c|c|c|c|c|}
\hline \multicolumn{6}{|c|}{ Fertility analysis } \\
\hline $\mathbf{P}$ & $\mathbf{p H}$ & $\mathbf{A l}$ & $\mathbf{C a}$ & $\mathbf{M g}$ & $\mathbf{K}$ \\
\hline $\mathrm{mg} / \mathrm{dm}^{3}$ & & \multicolumn{5}{|c|}{ meq./100 g of soil } \\
\hline 4 & 5.7 & 0.10 & 1.90 & 0.70 & 0.12 \\
\hline \multicolumn{7}{|c|}{ Chemical analysis } & $\mathbf{C}$ & MO & Saturated extract \\
\hline $\mathbf{N a}^{+}$ & $\mathbf{H}^{+}$ & $\mathbf{N}$ & $(\%)$ & CE $\times 10^{3}$ \\
\hline \multicolumn{7}{|c|}{$\mathrm{mg} / 100 \mathrm{~g}$ of soil } & & 1.32 & 2.28 & 0.308 \\
\hline 0.06 & 4.14 & 0.13 &
\end{tabular}


In the control treatments, $2 \mathrm{ml}$ of the soil filtrate solution $(1: 10$, soil:water, $v / v)$ was used to add natural microbiota (except AMF). Ten days after inoculation, the seedlings were transfered to plastic bags with $2 \mathrm{~kg}$ of soil and maintained in the greenhouse for 70 days.

\section{Determination of $P$ on shoots}

After harvest, the shoots were separated from the roots, dried at $65^{\circ} \mathrm{C}$, ground and processed for determining concentration of phosphorus by nitroperchloric digestion and spectrophotometric reading at $880 \mathrm{~nm}$.

\section{Mycorrhizal colonization}

Roots were rinsed in tap water, cleared with $10 \% \mathrm{KOH}(\mathrm{w}: \mathrm{v})$ and stained with Trypan blue (Phillips \& Hayman, 1970). Colonization was estimated by counting 50 root segments of each sample (Giovanetti \& Mosse, 1980) presenting characteristic mycorrhizal structures, such as arbuscules, vesicles, hypha, and auxiliary cells.

\section{Protein extraction}

After rinsing, sub-samples of roots were dried at room temperature, placed in plastic bags, and kept at $-4^{\circ} \mathrm{C}$. For protein extraction, $0.5 \mathrm{~g}$ of roots from each plant were placed in a mortar with liquid nitrogen and ground with $0.3 \mathrm{~g}$ sucrose and $0.3 \mathrm{~g}$ of PVP (polivinilpirrolidona). After that, $2 \mathrm{ml}$ of extraction buffer were added for new trituration. The buffer consisted of a mixture (1:9) of buffer

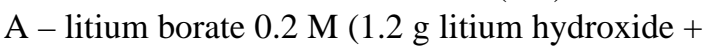
$11.89 \mathrm{~g}$ boric acid $+1,000 \mathrm{ml}$ distilled water $-\mathrm{pH}$ 8.3), and buffer B - tris-citrate $0.2 \mathrm{M}$ (1.6 citric acid $+6.2 \mathrm{~g}$ tris $+1,000 \mathrm{ml}$ distilled water $-\mathrm{pH}$ 8.3) (Scandalios, 1969). The macerated material was transfered to Eppendorfs and centrifuged at $14,000 \mathrm{rpm} / 10 \mathrm{~min}$. at $40^{\circ} \mathrm{C}$. The supernatant was either transfered to new tubes and immediately used for electrophoresis or frozen for later analysis. Protein concentration was estimated by the Bradford (1976) method through linear regression, using a BSA curve (bovine serum albumin) as a pattern.

\section{Electrophoresis}

For qualitative analysis, the samples were submitted to horizontal electrophoresis for native proteins in gel of $7 \%$ poliacrylamide $(72 \mathrm{ml}$ buffer A $+8 \mathrm{ml}$ buffer B), 0.28 bis-acrylamide, $5.32 \mathrm{~g}$ acrylamide, $0.8 \mathrm{ml}$ ammonium sulphate $(10 \%, \mathrm{w} / \mathrm{v})$, and $0.08 \mathrm{ml}$ TEMED. Each role received $10 \mathrm{ml}$ of root extract. The electrophoresis was carried out in constant current $(20 \mathrm{~mA})$ during 4 hours at $4^{\circ} \mathrm{C}$, using bromophenol blue as the carrier.

\section{Enzymatic colouring}

After electrophoretic running, the gel was immediately placed in the coloring solution for esterase (PO - EC 1.11.1.7) at room temperature for two hours in the dark (Alfenas et al., 1991). The coloring solution consisted of $0.06 \mathrm{~g} 3$-amino9-methyl-carbazole, $5 \mathrm{ml}$ dimethylphormamide, $2 \mathrm{ml} \mathrm{CaCl}_{2}$ (1 M), $6 \mathrm{ml} \mathrm{H} \mathrm{O}_{2}(3 \%$, v/v), $85 \mathrm{ml}$ sodium acetate buffer $0.05 \mathrm{M}$ [11.4 ml acetic acid $(0.2 \mathrm{M}), 27.2 \mathrm{~g}$ sodium acetate $(0.2 \mathrm{M}), 1,000 \mathrm{ml}$ distilled water]. The gel fixation with methanol solution, acetic acid, and distilled water, for 20 min., was followed by rinsing in tap water (Ayala, 1982).

\section{Densitometry}

For confirmation of the electrophoretic bands, after dehydration the gel was submitted to densitometric analysis at $520 \mathrm{~nm}$ of wave length.

\section{Statistical treatment}

Data were submitted to analysis of variance and correlation tests using the Statistic Program (Statsoft, 1995) and means were compared through the LSD ( $5 \%$ of significance). Values of colonization were transformed (arcosen of square root of percentage of root colonization/100).

\section{RESULTS}

\section{Root protein}

The concentration of root proteins in the treatments of fungi and soil $\mathrm{P}$ levels were not significantly different. However, comparison of means showed significant differences among roots receiving the inoculum mixture and kept in soil with $11 \mathrm{mg} \mathrm{P} / \mathrm{dm}^{3}$ of soil and among plants associated with G. albida, and in soils with $30 \mathrm{mg} \mathrm{P} /$ $\mathrm{dm}^{3}$ of soil, respectively with 445 and $137 \mu \mathrm{g}$ of protein. $\mathrm{ml}^{-1}$ of extract (Table 2).

The effects of each single species and of the mixture of AMF on values of root peptides were not significantly different when compared with colonized and noncolonized plants or even the inoculum treatments. 
TABLE 2

Effect of inoculation with arbuscular mycorrhizal fungi and soil $P$ levels in concentration of passion fruit root proteins.

\begin{tabular}{|c|c|}
\hline \multicolumn{1}{|c|}{ Treatments } & Protein concentration $(\mu \mathbf{g} / \mathbf{m l}$ of extract) \\
\hline $4 \mathrm{mg} \mathrm{P} / \mathrm{dm}^{3}$ & $289.66 \pm 159.95 \mathrm{ab}$ \\
\hline 2 & $408.66 \pm 147.02 \mathrm{ab}$ \\
\hline 3 & $256.00 \pm 105.07 \mathrm{ab}$ \\
\hline 4 & $416.66 \pm 190.89 \mathrm{ab}$ \\
\hline $11 \mathrm{mg} \mathrm{P} / \mathrm{dm}^{3}$ & \\
\hline 1 & $308.66 \pm 215.94 \mathrm{ab}$ \\
\hline 2 & $416.33 \pm 159.10 \mathrm{ab}$ \\
\hline 3 & $286.33 \pm 155.53 \mathrm{ab}$ \\
\hline 4 & $445.00 \pm 319.69 \mathrm{bc}$ \\
\hline 1 & \\
\hline 2 & $272.33 \pm 53.37 \mathrm{ab}$ \\
\hline 3 & $137.33 \pm 95.09 \mathrm{a}$ \\
\hline 4 & $200.33 \pm 166.29 \mathrm{ab}$ \\
\hline $\mathrm{mg} \mathrm{P} / \mathrm{dm}^{3}$ & $266.00 \pm 113.87 \mathrm{ab}$ \\
\hline
\end{tabular}

1 - non-inoculated; 2- Gigaspora albida; 3-Scutellospora heterogama; 4-mixed inoculum (G. albida, G. margarita, S. heterogama and Glomus etunicatum). Means followed by the same letter are not significantly different from the LSD test at $5 \%$.

For the soil $\mathrm{P}$ factor, there were significant differences in protein concentrations between roots maintained in soils with $11 \mathrm{mg} \mathrm{P} / \mathrm{dm}^{3}$ and those kept in soil with $30 \mathrm{mg} \mathrm{P} / \mathrm{dm}^{3}$ of soil (Table 3).

Significative negative correlation was observed between values of protein and soil $\mathrm{P}$ concentration $(-0.41)$ which was not observed in concentration of this mineral in plant tissues.

\section{Isoenzymatic activity}

Peroxidase marking in gel electrophoresis presents few differences among extracts of the treatments, specifically in relation to mycorrhizal and non-mycorrhizal plants. The samples presented one band in common, which was less intense in non-colonized plants grown in soils with 11 and $30 \mathrm{mg} \mathrm{P} / \mathrm{dm}^{3}$ of soil (lines 5 and 9, Fig. 1). However, from the protein amount, it was observed that this effect was not proportional to the concentration of total proteins, since more strongly marked samples received lesser amounts of protein than the others (lines 9 and 10, Fig. 1) with 2.32 and $1.69 \mu \mathrm{g}$ of protein. $\mathrm{ml}^{-1}$ of extract, respectively. This indicates not only a quantitative but also a proportional alteration.

In most of the samples, there was a band above the main one, which was absent in non-inoculated plants grown in substrate with less $\mathrm{P}$ amounts (treatments 1 and 5). In the control roots, at the level of $3 \mathrm{mg} \mathrm{P} / \mathrm{dm}^{3}$ of soil (treatment 1) a band with lower molecular weight (rf: 0.46) was observed that was not present in the other extracts. Specific bands for mycorrhizal activity, which were expected in associated plants, were not seen.

\section{DISCUSSION}

Absence of significative variance among protein values in the treatments differs from earlier results where qualitative-quantitative physiological changes in the gene expression of fungi and hosts producing different families of proteins were registered. 


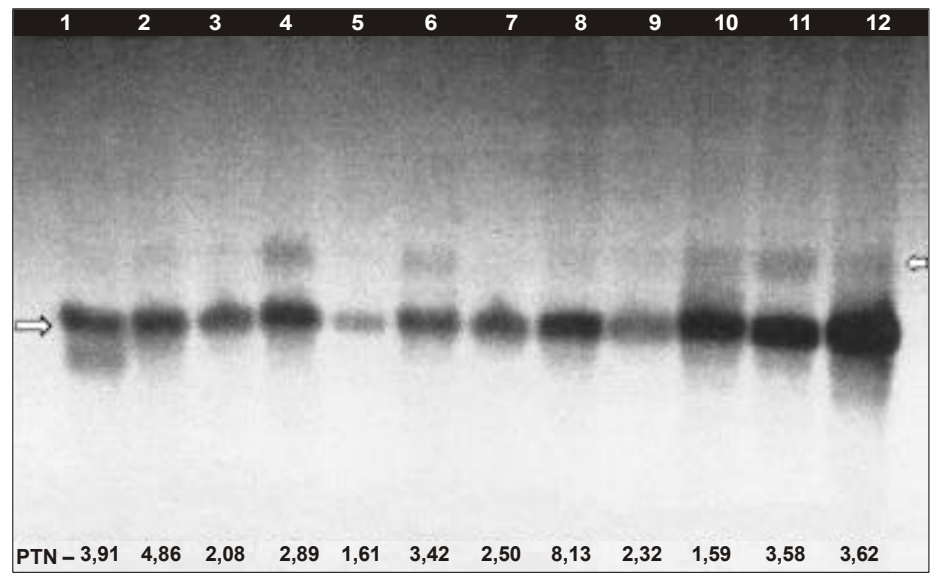

Fig. 1 - Peroxidase activity (PAGE - 7\%) in extract of passion fruit roots, grown in soils with $4 \mathrm{mg}$ P/dm $\mathrm{dm}^{3}$ of soil $(1,2$, $3,4), 11 \mathrm{mg} \mathrm{P} / \mathrm{dm}^{3}$ of soil $(5,6,7,8)$, and $30 \mathrm{mg} \mathrm{P} / \mathrm{dm}^{3}$ of soil $(9,10,11,12)$. Lines 1,5 and 9: non-inoculated; 2,6 and 10: Gigaspora albida; 3, 7 and 11: Scutellospora heterogama; 4, 8 and 12: mixed inoculum (G. albida, G. margarita, S. heterogama and Glomus clarum). Big arrow: common band for all extracts. Small arrow: varied band, absent in control treatments, with lower levels of soil P. PTN = amount of proteins applied.

TABLE 3

Effect of soil $P$ level in the concentration of passion fruit root proteins.

\begin{tabular}{|c|c|}
\hline Level of soil $\mathbf{P}\left(\mathbf{m g} / \mathbf{d m}^{\mathbf{3}}\right)$ & Protein concentration $(\boldsymbol{\mu g} / \mathbf{m l ~ o f ~ e x t r a c t )}$ \\
\hline 4 & $342.75 \pm 150.70 \mathrm{ab}$ \\
\hline 11 & $364.08 \pm 202.67 \mathrm{~b}$ \\
\hline 30 & $219.00 \pm 113.31 \mathrm{a}$ \\
\hline
\end{tabular}

Means followed by the same lether are not significantly different by the LSD test at $5 \%$.

In a revision paper, Gianinazzi-Pearson \& Gianinazzi (1995) observed that results showing increases in protein concentration in root extracts of mycorrhizal plants are more frequentely found. Arines et al. (1993) also noticed high content of protein in roots of Trifolium pratense L. colonized by Glomus mosseae, although noting that during development of arbuscular mycorrhiza, changes in the polypeptyde expression happens in low levels, and that purification of the extracts is necessary in order to visualize possible changes in genetic translation. In our research, the extracts were not purified and this might have interfered in the results. Statistical differences among means of root proteins when soil P effect is observed, may demonstrate the role of this mineral on regulation of symbiosis through synthesis, stimulation, or activation of proteins and enzymes (Lambais \& Mehdy, 1995). Smith et al. (1985) studied the effect of mycorrhization and phosphate fertilization on the expression of glutamate synthetase (GS) and glutamate dehydrogenase (GD) in roots and shoots of T. subterraneum and Allium cepa. For T. subterraneum the authors did not observe an apparent effect of mycorrhization or fertilization on activity of GD in plant tissues. In GS the activity was low when plants developed in soil deficient in $\mathrm{P}$, but increased with $\mathrm{P}$ fertilization and mycorrhizal colonization, which made it difficult to isolate the effect of each factor. In onion plants, similar responses were observed with increase in enzymatic activity (GS) following directly the soil $\mathrm{P}$ level and intensity of colonization by AMF. Conversely, Gianinazzi et al. (1992) pointed out that the activity of alcaline phosphatases is enhanced when the host plant grows in P-deficient substrates. These data agree with those of Tibbett et al. (1998) who mentioned that with species of the ectomy- 
corrhizal fungus Hebeloma there was increase of production of acid phosphatase when the microrganisms were maintained in media with low organic P. This may demonstrate the strong effect of this mineral on the physiology of all mycorrhiza, not only on those of the arbuscular type. However, Epstein (1975) emphasizes that phosphorus has a direct effect on diverse enzymatic plant processes, very often acting as a biochemical co-factor. Detailed studies regarding effects of $\mathrm{P}$ and fungal colonization on protein expression of roots are preliminary, and a higher number of observations are necessary for broad understanding of this process. Lambais (1996) mentioned that for some authors the association would be regulated by the $\mathrm{P}$ level in plant tissues and not by the soil P level.

There was no significant interaction between amount of $\mathrm{P}$ on plant shoots and amount of root peptides. This can be due to problems related with the time $(70 \mathrm{~d})$ for harvesting the experiment. O'Keefe \& Sylvia (1992) affirmed that P absorbtion may have more impact at the beginning of mycorrhizal colonization. The soil $\mathrm{P}$, however, presented negative interaction with protein concentration. This may indicate an inhibitory effect on expression of some proteins, occasionally more greatly produced during the physiological stage in which the plants were harvested. These effects were mentioned before in some mycorrhizal interactions (Gianinazzi et al., 1992; Tibbett et al., 1998). Peroxidase activity has been investigated as a marker of mycorrhizal development since it works in the plant defense system. Spanu \& Bonfante-Fasolo (1988) observed that the zimogram of peroxidase showed less strong bands in noninoculated plants grown in intermediate and high $\mathrm{P}$ concentrations, which is in accordance with results of Dehne \& Schönbeck (1978). Spanu \& Bonfante-Fasolo (1988) noticed high amount of peroxidases from cell walls of Allium porrum $\mathrm{L}$. roots which were beginning mycorrhizal development (16 d); after that there was a decrease in activity which, reached the same level that of noncolonized plants (50 d). For the authors, this might be due to the direct effect of AMF (Glomus versiforme) with massive colonization signifying a low level of enzymatic activity and vice versa. These data support the idea that low levels of hydrolitic enzyme activity and transcription of plant defense genes would be related with delayed recognition between the partners, promoting the functional integrity of the symbioses (Morh et al., 1998; Blilou et al., 1998). However, differences found in the responses may be due to variations in the methodology used (soluble enzymes or those from cell wall) or even may reflect the result of the complexity of the mycorrhizal system regarding evaluation of peroxidase activity on colonized and noncolonized plants.

The additional band observed on the control extract may demonstrate an inhibitory effect of the mycorrhizal fungus or the effect of high concentration of soil P on translation of specific genes. GarcíaGarrido et al. (1999) studied the effect of xyloglucans on expression of endo- and exoxyloglucanases, observing that many bands present in non mycorrhizal material were absent in the association as well as in the mycelium, which suggests qualitative inhibitions in some host activities. Although some investigations have demonstrated the effect of concentration of soil $\mathrm{P}$ on enzyme expression, there are no data available connected with peroxidase. Effect of this factor (P concentration) on intensities of enzymatic band was not detected in our studies.

The inoculation with different isolates (alone or in a mixture) did not affect the amount of protein in passion fruit, indicating an indifferentiated reaction of this plant in relation to mycorrhizal colonization. In some cases, purification of the root extract is necessary in order to show its quantitative alterations. On the other hand, soil P level had a more relevant effect on the genetic expression, which reinforce theories regarding defense systems and control of symbioses as being modulated by $\mathrm{P}$ amount in the soil.

Peroxidase activity apparently responds more strongly to the fungus effect, presenting bands with low intensity for non-mycorrhizal plants (except for treatment 1). The appearance of enzymatic bands in material from noncolonized roots may indicate an inhibitory effect of AMF colonization on the expression of some host root protein. For mycorrhiza formed between passion fruit and the AMF tested, peroxidase dye is not useful as an ecophysiological marker, since mycorrhizal specific bands were not observed.

Acknowledgments - The authors are grateful to Dr. Luiza S. S. Martins and Nara S. Freitas (UFRPE), for support on the methodology and to the Central Laboratory (Lacem) of the Secretaria de Saúde de Pernambuco for allowing the use of some equipment. Financial support was provided by Capes and $\mathrm{CNPq}$. 


\section{REFERENCES}

ALFENAS, A. C., PETERS, I., BRUNE, W. \& PASSADOR, G. C., 1991, Eletroforese de proteínas e isoenzimas de fungos e essências florestais. Universidade Federal de Lavras, Lavras, MG, 242p.

ARINES, J., PALMA, M. J. \& VILARIÑO, A., 1993, Comparison of protein patterns in non-mycorrhizal and vesicular-arbuscular mycorrhizal roots of red clover. New Phytol., 123: 763-768.

AVIO, L. \& GIOVANNETTI, M., 1998, Variability in protein profiles among species, isolates and physiological states of arbuscular mycorrhizal fungal spores. In: U. Alhonen-Jonarth, E. D. P. Fransson, O. Karén, B. Lindahl, I. Rangel \& R. Finlay (eds.), Programe and $A b$ stract of the Second International Conference on Mycorrhiza. Uppsala, Sweden, p. 21.

AYALA, F. J., 1982, Genetic variation in natural population: problem of eletrophoretically cryptic alleles. Proceedings of the National Academy (USA), 79: 550-554.

BLILOU, I., BUENO, P., GARCÍA-GARRIDO, J. M. \& OCAMPO, J. A., 1998, Catalase and peroxidase in tobacco roots inoculated by Glomus mosseae. In: U. Alhonen-Jonarth, E. D. P. Fransson, O. Karén, B. Lindahl, I. Rangel \& R. Finlay (eds.), Programe and Abstract of the Second International Conference on Mycorrhiza. Uppsala, Sweden, p. 31.

BONFANTE-FASOLO, P. \& SPANU, P., 1994, Pathogenic and endomycorrhizal association. In: J. R. Morris, D. Read \& A. K. Varma (eds.), Techniques for Mycorrhizal Research - Methods in Microbiology. Academic Press, London, pp. 602-628.

BRADFORD, M. M., 1976, A rapid and sensitive method for the quantification of microgram quantities of protein utilizing the principle of protein-dye binding. Anal. Biochem., 72: 248-254.

CAVALCANTI, S. J. A., SANTOS, J. C. T., PEREIRA, J. R., LEITE, J. F., SILVA, M. C. L., FREIRE, S. J., SILVA, D. J., SOUSA, A. R., MESSIAS, A. S., FARIA, C. M. B., BURBOS, N., LIMA-JÚNIOR, M. A., CAVALCANTI, A. L. \& LIMA, J. S. W. S., 1998, Recomendações de adubação para o estado de Pernambuco: $2^{a}$ aproximação. Empresa Pernambucana de Pesquisa Agropecuária (IPA), Recife, PE, 198p.

DEHNE, H. W. \& SCHÖNBECK, F., 1978, Untersuchugen zum Einfluss der endotrofen Mykorrhiza auf Pfanzenkkrankheiten. 3. Chiotinase - Aktivitate und Ornithinzyklus. Z. Pflanzen. Pflanzenschuts, 85: 666-678.

EPSTEIN, E., 1975, Nutrição mineral das plantas - princípios e perspectivas. Editora da Universidade de São Paulo, São Paulo, 344p.

GARCÍA-GARRIDO, J. M., REJON-PALOMARES, A., OCAMPO, J. A. \& GARCÍA-ROMERA, I., 1999, Effect of xyloglucan and xyloglucanase activity on the development of arbuscular mycorrhizal Glomus mosseae. Mycol. Res., 103(7): 882-886.
GIANINAZZI, S., GIANINAZZI-PEARSON, V., TISSERANT, B. \& LEMOINE, M. C., 1992, Protein activities as potencial markers of funcional endomycorrhizas in plant. In: D. J. Read, D. H. Lews, A. H. Fitter \& I. J. Alexander (eds.), Mycorrhizas in Ecosystems. CAB International, Oxon, pp. 333-339.

GIANINAZZI-PEARSON, V., 1992, Recent research into the cellular, molecular and genetical bases of compatible host-fungus interactions in (vesicular) arbuscular endomycorrhiza: approaches and advances. In: Interactions plants microoganismes. International Foundation for Science, Dakar, Senegal, pp. 253-263.

GIANINAZZI-PEARSON, V. \& GIANINAZZI, S., 1995 , Proteins and proteins activities in endomycorrhizal simbioses. In: V. Varna \& B. Hock (eds.), Mycorrhiza. Springer-Verlag, Berlin, pp. 251-266.

GIOVANETTI, M. \& MOSSE, B., 1980, An evaluation of techniques for measuring vesicular arbuscular mycorrhizal infection in roots. New Phytol., 84: 489-500.

HEPPER, C. M. \& SEM, R., 1986, Biochemical characterization of vesicular-arbuscular mycorrhizal fungi. In: $1^{o}$ ESM. INRA, Paris, pp. 611-614.

LAMBAIS, M. R., 1996, Aspectos bioquímicos e moleculares da relação fungo-planta em micorrizas arbusculares. In: J. O. Siqueira (ed.), Avanços em Fundamentos e Aplicação de Micorrizas. UFL., Lavras, MG, pp. 5-38.

LAMBAIS, M. R. \& MEHDY, M. C., 1995, Differential expression of defense-related genes in arbuscular mycorrhiza. Can. J. Bot., 73(suppl. 1): S533-S540.

MOHR, U., LANGE, J., BOLLER, T., WIEMKEN, A. \& VÖGELI-LANGE, R., 1998, Plant defense genes are induced in the pathogenic interaction between bean roots and Fusarium solani, but not in the symbiotic interaction with the arbuscular mycorrhizal fungus Glomus mosseae. New Phytol., 138: 589-598.

O’KEEFE, D. M. \& SYLVIA, D. M., 1992, Chronology and mechanisms of P uptake by mycorrhizal sweet potato plants. New. Phytol., 122: 651-659.

PHILLIPS, J. M. \& HAYMAN, D. S., 1970, Improved procedures for clearing roots and staining parasitic and vesicular arbuscular mycorrhizal fungi for rapid assessment of infection. Trans. Br. Mycol. Soc., 55: 158-161.

SCANDALIOS, J. G., 1969, Genetic control of multiple molecular forms of enzymes in plants: a review. Biochem. Genetics, 3: 37-39.

SMITH, S. E., St. JOHN, J., SMITH, F. A. \& NICHOLAS D. J. D., 1985, Activity of glutamine synthetase and glutamato dehydrogenase in Trifolium subterraneum $\mathrm{L}$. and Allium cepa L.: effects of mycorrhizal infection and phosphate nutrition. New Phytol., 99: 211-227.

SPANU, P. \& BONFANTE-FASOLO, P., 1988, Cell-wallbound peroxidase activity in roots of mycorrhizal Allium porrum. New Phytol., 109: 119-124.

STATSOFT, 1995, Statistics for Windows. Tulsa, USA.

TIBBETT, M., ENDERS, F. E. \& CAIRNEY, J. W. G., 1998, The effect of temperatute and inorganic phosphorus supply on growth and acid phosphatase production in artic temperature and temperature strains of ectomycorrhizal fungi Hebeloma spp. in axenic culture. Mycol. Res., 102(2): 129-135. 